\title{
Small Business Success or Failure Prediction: A Comparative Study in Ghana and Israel
}

\author{
Prince Gyimah \\ University of Education, Winneba, Kumasi-Campus \\ Shaike Marom \\ Hiram College
}

Robert N. Lussier

Springfield College

This paper tests the Lussier success versus failure prediction model in Ghana, an emerging country and Israel, a developed country. The logit results of Israel $(N=205 ; p=0.000)$ and Ghana $(N=208 ; p=$ 0.000) support the model validity to predict the success or failure of a group of businesses. The accuracy rate of predicting a specific business as successful or failure was greater than 85 percent in both countries, with high $R$ square. Testing the $t$-values of the individual variables in each country revealed some differences between the two countries; results and implications are presented.

\section{INTRODUCTION}

Small businesses contribute significantly to the economic growth, development, employment, and social cohesion in every country (Buyinza, Mutenyo, Kakande and Banga, 2017; OECD, 2015). For example, small businesses contribute 67 percent to employment and 58 percent to GDP in European countries (European Union, 2012). In Israel, they represent 99 percent of the businesses and contribute to 55 percent of GDP (Israel MITL, 2010). They also represent 92 percent of the businesses and employ 80 percent of the workers in Ghana (Abor, 2016). Small businesses reduce poverty by providing basic needs such as food, clothes, and education, and help create the enabling environment in developing countries (Abor and Quartey, 2010). Unfortunately, many small businesses fail within the first five years (Pena, 2004).

Understanding why entrepreneurs fail or succeed has become an important area in research due to the significant roles they play in every country (Lussier and Halabi, 2010). However, there is great discrepancy in prior studies because researchers have failed to clearly list the factors that contributes to small business success or failure (Lussier, Bandara and Marom, 2016). Studies on small firms do not provide a comprehensive explanation of why small firms failed (Lussier, 2005; Lussier and Pfeifer, 2001), and currently there is no unified theory (Hyder and Lussier, 2016). In addition, Oviatt and McDougall (2005) and Bono and McNamar (2011) emphasized the need to test models in different countries to access their robustness. 
This study contributes to the literature by testing the Lussier (1995) success versus failure prediction model in Ghana (Africa) where there are no prior studies and compares results to the Middle East region, Israel. This study supports the Lussier (1995) model as a global predictor of success or failure. Educators, consultants, and government agencies that train, advice and assist small business owners can teach the model and help them use the model to assess the probability of success vs failure. Future and current entrepreneurs; lenders, investors, and suppliers; and public policy makers can use the model to increase the probability of successful entrepreneurial ventures.

\section{LITERATURE REVIEW}

\section{Development and Selection of the Prediction Model}

The development of success or failure prediction models was started with univariate models pioneered by Beaver (1966), and other quantitative prediction models have been developed (Altman, 1968; Altman, Haldeman and Narayanan, 1977; Altman and Sabato, 2007; Beaver, 1966; Blum, 1974; Deakin, 1977; Ohlson, 1983). Most of the early research studies were based on prediction models for large firms due to the availability and accessibility of financial data. However, the use of financial data for success or failure prediction has been questioned (Appiah, 2011; Gyimah and Boachie, 2018). For instance, Rosner (2011) asserts that financial data can be manipulated and is not appropriate for start-up ventures.

Lussier (1995) recommended that the use of non-financial models can be used to predict success or failure of businesses more accurately than financial models, especially with start-up ventures with no financial history. Argenti (1976) develop a non-financial model known as A-score model for predicting corporate failure. Argenti model was the starting point for failure prediction for companies with no financial history (Morris, 1995). However, the model has not been validated for entrepreneurial studies because some of the model variables demand financial ratios that are not available for new ventures, and it was mainly developed for large firms. Due to significant contributions of small businesses to economic growth and development, some prior researchers developed a few important models that concentrated on small business (Cooper et al., 1991; Dennis and Fernald, 1990; Gaskill et al., 1993; Lussier, 1995; Reynolds and Miller, 1989).

The Lussier model was created in the United States to better understand why some businesses succeed and others fail, and to predict success vs failure. The model consists of 15 variables that were selected from 20 prior studies identified as contributing factors of success versus failure of small businesses. The model is also more appropriate for small businesses with no financial history. Also, the model is relevant because it consists of three important aspects namely the owner characteristics, the business characteristics, and the economic cycle of the business (Carrero-Morales, 2015). The owner's characteristics include age, managerial and industrial experience, educational background, marketing skills, business background, owner's parents and ethnic origin (minority). The business characteristics includes capital, business plan, partnership, record keeping and financial control, product or services timing, quality staffing and the use of professional advisors. Lastly, economy cycle represents economy timing (whether in recession or expansion) when the business start operations.

Though there has not been a universal accepted theory that underpin what constitute the success versus failure prediction variables, Lussier (1995) used resource-based theory as entrepreneurs make judgments about which resources are more or less importance for the development of their venture (Lussier and Halabi, 2010). This study tested the Lussier (1995) model because model it is the most extensive model which has been validated for small business research (Dennis and Fernald, 2001; Teng et al., 2011). Table 1 shows the 15 variables of Lussier (1995) model. 


\title{
TABLE 1
}

\section{LUSSIER MODEL VARIABLES}

\author{
Success Versus Failure Variables
}

Capital (capt). Businesses that start undercapitalized have a greater chance of failure than firms that start with adequate capital.

Record keeping and financial control ( $r k f c)$. Businesses that do not keep updated and accurate records and do not use adequate financial controls have a greater chance of failure than firms that do.

Industry Experience (inex). Businesses managed by people without prior industry experience have a greater chance of failure than firms managed by people with prior industry experience.

Management Experience (maex). Businesses managed by people without prior management experience have a greater chance of failure than firms managed by people with prior management experience.

Planning (plan). Businesses that do not develop specific business plans have a greater chance of failure than firms that do.

Professional Advisors (prad). Businesses that do not use professional advisors have a greater chance of failure than firms using professional advisors. A more recent source of professional advisors is venture capitalists.

Education (educ). People without any college education who start a business have a greater chance of failing than people with one or more years of college education.

Staffing (staff). Businesses that cannot attract and retain quality employees have a greater chance of failure than firms that can.

Product/Service Timing (psti). Businesses that select products/services that are too new or too old have a greater chance of failure than firms that select products/services that are in the growth stage.

Economic Timing (ecti). Businesses that start during a recession have a greater chance of failing than firms that start during expansion periods.

Age (age). Younger people who start a business have a greater chance of failing than older people starting a business.

Partners (part). A business started by one person has a greater chance of failure than a firm started by more than one person.

Parents (pent). Business owners whose parents did not own a business have a greater chance of failure than owners whose parents did own a business.

Minority (mior). Minorities have a greater chance of failure than non-minorities.

Marketing (mrkt). Business owners without marketing skills have a greater chance of failure than owners with marketing skills.

\section{Empirical Review}

Business success vs failure studies have been conducted in both developing and developed countries. In developed countries, Blackwood and Mowl (2000) conducted a study in Spain and concluded that success or failure depends on the behaviors of business owners, social behaviors, and the economic factors of the environment. Lussier (1995) found that staffing, education, planning, and professional advice contributes to success of businesses in United States. Teng et al. (2011) found that marketing skills of entrepreneurs and product and service timing determines business success in Singapore. Cooper et al. (1990, 1991), Reynolds and Miller (1989), and Reynolds (1987) found adequate capital as the predictor of business success.

Some studies found entrepreneurial characteristics of businesses owners as contributing factors of business success or failure. For instance, Storey (1994); Duchesneau and Gartner (1990); Lussier and Pfeifer (2001); Barkham et al. (1996); Kangasharju (2000) stipulates that owners age is a predictor of performance of small businesses. Other studies contribute the success or failure of businesses to 
psychological traits like specific managerial skills, experience, training and business environment (Dess et al., 1997; Rauch and Frese, 2000).

Empirical studies in developing economies link variables such as environmental conditions and managerial skills as the key determinant of performance of small businesses (Huck and McEwen, 1991; Yusuf, 1995). For instance, in Kenya, Neshamba (2000) found out that previous experience of owners or managers, the understanding of customer's needs, capital accessibility and hard work contributes to the success of a business.

Table 2 summarizes the factors identified from 35 prior research studies that contributes to Lussier (1995) success versus failure prediction model variables. As shown, there are large discrepancies in the literature. Thus, there currently is no theory (Lussier et al., 2016). 


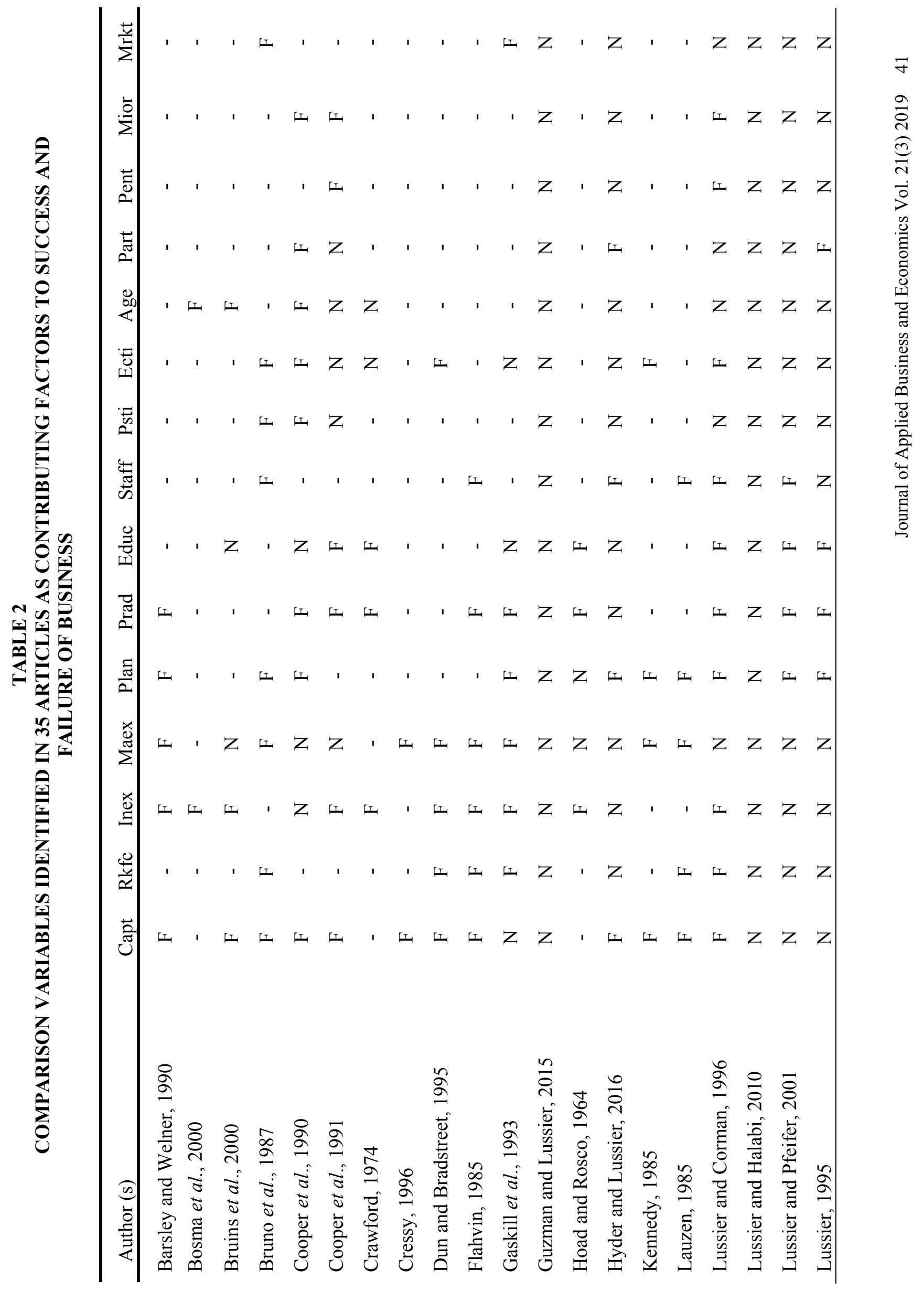




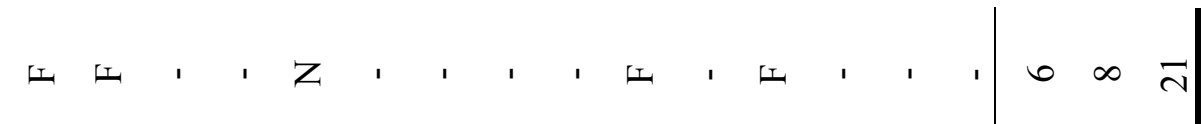

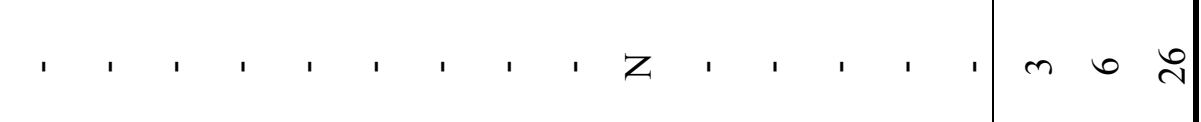

$$
\begin{aligned}
& 1,1,1,1,1, z, 1,1,1,100
\end{aligned}
$$

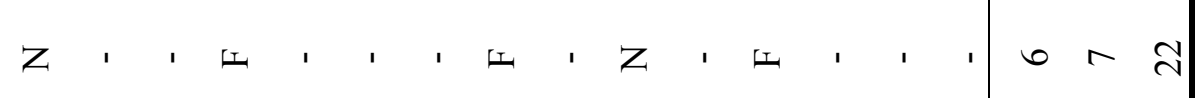

$$
\begin{aligned}
& 1,1, z, 1,1, \quad \text {, } 1,1,1,1, n \in
\end{aligned}
$$

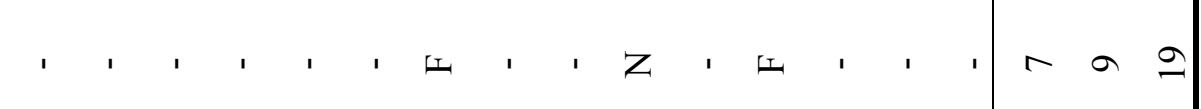

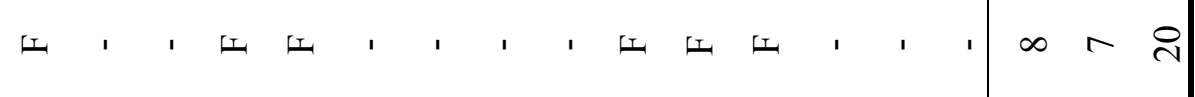

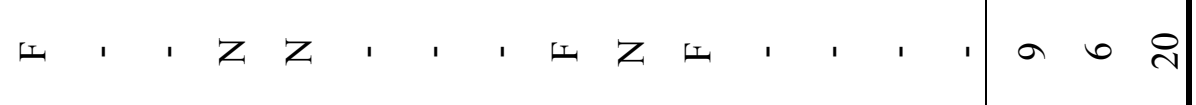

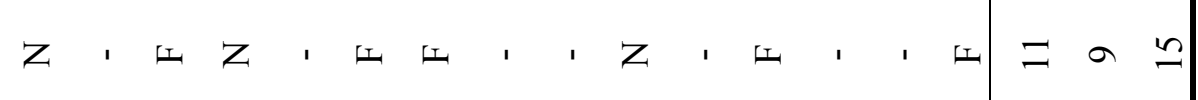

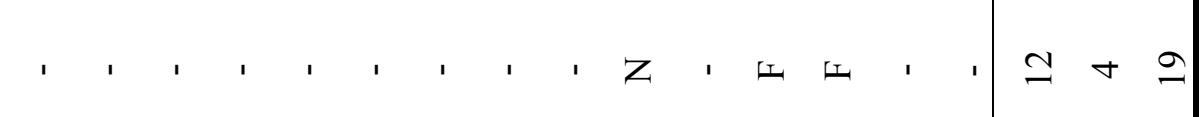

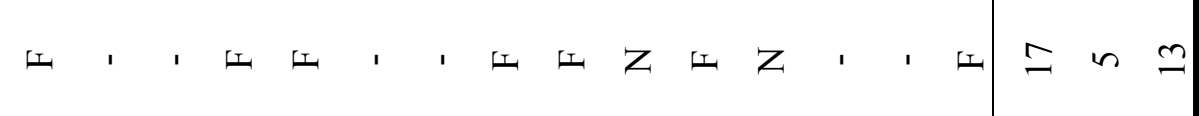

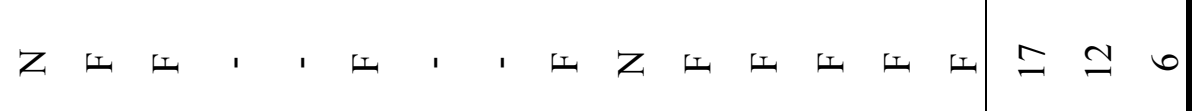

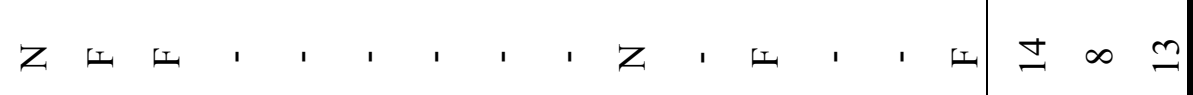

$$
\begin{aligned}
& \text { 山 ' } \\
& \text { 乙山 }
\end{aligned}
$$

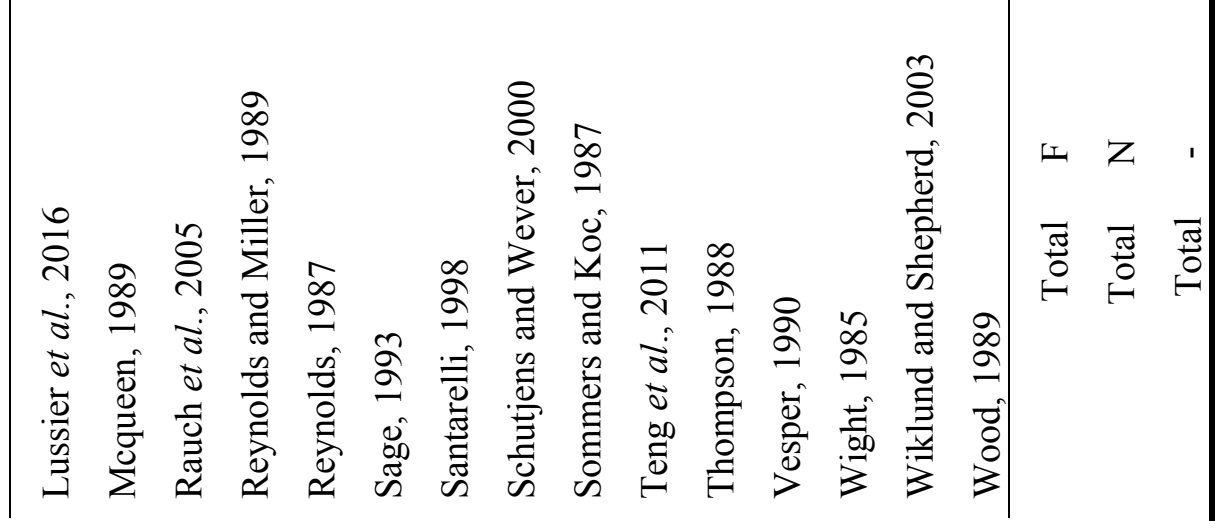




\section{METHOD}

\section{Survey Instrument}

This study is survey research using quantitative analysis. The study used the Lussier (1995) questionnaire that has been previously validated in different countries and compares Ghana result with the prior Israeli study (Marom and Lussier, 2014). The Israeli study translated the Lussier questionnaire to Hebrew, whereas the Ghana study used the original questionnaire since the official language for Ghana is English. The questionnaire was pilot tested in both countries for content validity.

\section{Model and Measurement}

The analytical model for the study is in the form of a logit regression. The formula to predict a logit transformation of the probability of 15 -success versus failure independent variables is as follows:

$$
\begin{aligned}
\operatorname{logit}(p)= & \beta_{0}+\beta_{1} C A P T+\beta 2 R K F C+\beta_{2} I N E X+\beta_{1} M A E X+\beta_{1} P L A N+\beta_{1} P R A D+\beta_{1} E D U C+\beta_{1} S T A F F \\
& +\beta_{1} P S T I+\beta_{1} E C T I+\beta_{1} A G E+\beta_{1} P A R T+\beta_{1} P E N T+\beta_{1} M I O R+\beta_{1} M R K T
\end{aligned}
$$

where: $\mathrm{p}$ is dichotomous variable, that is, business success $(\mathrm{s}=1)$ or failure $(\mathrm{f}=0)$;

$\beta_{0}$ is the constant value;

$\mathrm{B}_{1 \text { to } 15}$ are the estimated values; and

CAPT to MRKT are the Lussier 15 model variables.

Notes under Table 3 indicates the measures of each of 15 variables.

The Lussier dependent variable is the level of performance measured nominally as successful or failed. A firm is categorized as successful if it is currently in operation and making profits. Unlike Israel, Ghana does not have a bankruptcy court to select failed firms to matched against successful firms. Thus, businesses that are currently losing money or the level of profit is below average are categorized as failure.

\section{Data Collection}

Ghana and Israel studies used random sampling techniques to select small businesses. This method is commonly used in firm level studies (Brush, Manolova and Edelman, 2008; Halabi and Lussier, 2014). In Ghana, a total of 750 questionnaires were sent and 307 were completed; resulting in a 40.9 percent response rate. In Israel, 242 of 340 businesses completed the survey; resulting in a 71 percent response rate. However, there were some missing and incomplete responses from participates in the survey. Thus, in Ghana, the actual sample size was 208 with 107 successful business and 101 failed firms. In Israel, the sample size was 205 with 104 successful business and 101 failed firms.

\section{RESULTS AND DISCUSSION}

Table 3 shows the descriptive statistics and test of difference of the 15 independent variables for 205 Israeli and 208 Ghanaian businesses. Table 4 shows the correlation between variables, and Table 5 has the logistic regression analysis of Lussier model for both countries. 
TABLE 3

DESCRIPTIVE STATISTICS FOR ISRAEL AND GHANA

\begin{tabular}{|c|c|c|c|c|c|c|c|c|}
\hline \multicolumn{5}{|c|}{ Israel (Middle East) } & \multicolumn{4}{|c|}{ Ghana (Africa) } \\
\hline $\begin{array}{c}\text { Model } \\
\text { Code }\end{array}$ & $\begin{array}{c}\text { Failed } \\
\text { Mean } \\
(n=101)\end{array}$ & $\begin{array}{l}\text { Failed } \\
\text { S.D. }\end{array}$ & $\begin{array}{l}\text { Success } \\
\text { Mean } \\
(n=104)\end{array}$ & $\begin{array}{c}\text { Success } \\
\text { S.D. }\end{array}$ & $\begin{array}{c}\text { Failed } \\
\text { Mean } \\
(n=101)\end{array}$ & $\begin{array}{c}\text { Failed } \\
\text { S.D. }\end{array}$ & $\begin{array}{c}\text { Success } \\
\text { Mean } \\
(n=107)\end{array}$ & $\begin{array}{c}\text { Success } \\
\text { S.D. }\end{array}$ \\
\hline 1. $\mathrm{CAPT}^{1}$ & 4.15 & 1.31 & 3.04 & $1.03^{* *}$ & 4.77 & 1.78 & 2.37 & $1.50^{* * * 6}$ \\
\hline 2. RFTC & 3.52 & 1.23 & 4.86 & $0.96^{* *}$ & 3.19 & 2.91 & 4.52 & $3.00^{* *}$ \\
\hline 3. INEX & 3.46 & 2.19 & 3.63 & 1.95 & 4.86 & 3.50 & 4.77 & 3.32 \\
\hline 4. MAEX & 3.53 & 2.12 & 2.48 & $1.77^{* *}$ & 4.61 & 3.06 & 4.55 & 3.36 \\
\hline 5. PLAN $^{1}$ & 3.53 & 1.28 & 2.18 & $0.76^{* *}$ & 4.05 & 1.95 & 3.64 & $1.75^{*}$ \\
\hline 6. PRAD $^{1}$ & 3.95 & 1.26 & 2.97 & $1.23^{* *}$ & 2.55 & 2.64 & 2.40 & 2.55 \\
\hline 7. EDUC & 1.39 & 0.86 & 1.57 & 0.82 & 2.63 & 1.33 & 2.89 & 4.46 \\
\hline 8. STAFF $^{1}$ & 4.62 & 1.26 & 5.04 & $0.99^{* *}$ & 3.26 & 2.30 & 3.27 & 2.25 \\
\hline 9. PSTI $^{1}$ & 4.18 & 1.3 & 4.43 & 0.96 & 2.51 & 1.34 & 2.35 & 1.22 \\
\hline 10. ECTI & 4.05 & 0.79 & 4.50 & $0.71^{* *}$ & 3.55 & 2.98 & 3.02 & 2.85 \\
\hline $\begin{array}{l}\text { 11. AGE } \\
\text { 12. PART }\end{array}$ & $\begin{array}{c}34.21 \\
{[30 / 30 \%]}\end{array}$ & 5.44 & $\begin{array}{c}31.5 \\
{[29 / 28 \%]}\end{array}$ & $3.63^{* *}$ & $\begin{array}{c}33.97 \\
{[50 / 50 \%]}\end{array}$ & 8.61 & $\begin{array}{c}34.51 \\
{[55 / 51 \%]^{*}}\end{array}$ & 8.35 \\
\hline $\begin{array}{l}\text { 13. PENT } \\
\text { 14. MIOR } \\
\text { 15. MRKT }\end{array}$ & $\begin{array}{c}{[36 / 36 \%]} \\
{[24 / 24 \%]} \\
3.75\end{array}$ & 1.24 & $\begin{array}{c}{[39 / 38 \%]} \\
{[20 / 19 \%]} \\
3.9\end{array}$ & 1.39 & $\begin{array}{c}{[40 / 40 \%]} \\
{[17 / 17 \%]} \\
2.19\end{array}$ & 2.40 & $\begin{array}{c}{[55 / 51 \%]} \\
{[16 / 15 \%]} \\
6.05\end{array}$ & $2.20^{* * *}$ \\
\hline
\end{tabular}

Note: $C A P T=$ Capital (1 adequate -7 inadequate); RFTC $=$ Record keeping and financial control (1 poor - 7 good); INEX = Industry experience (number of years); MAEX = Management experience (number of years); PLAN = Planning (1 specific -7 no plan); PRAD = Professional advice (1 used -7 not used); EDUC = Education (1 none -7 PhD); STAFF = Staffing (1 easy -7 difficult); PSTI = Product/Service timing (1 introduction -7 decline); ECTI = Economic timing (1 recession -7 expansion); $A G E=$ Age of owner (number of years); PART = Partners (number of partners in \%); PENT = Parents (number of parents that owned a business in \%); MIOR = Minority (number of minority/foreigners in \%); and MRKT = Marketing (1 unskilled -7 skilled).

${ }^{1}$ These model codes are reverse scale variables. Hence, a lower value is expected.

Significance level: $* * * \mathrm{p}<0.01$

$$
\begin{array}{r}
* * \mathrm{p}<0.05 \\
* \mathrm{p}<0.10
\end{array}
$$

44 Journal of Applied Business and Economics Vol. 21(3) 2019 


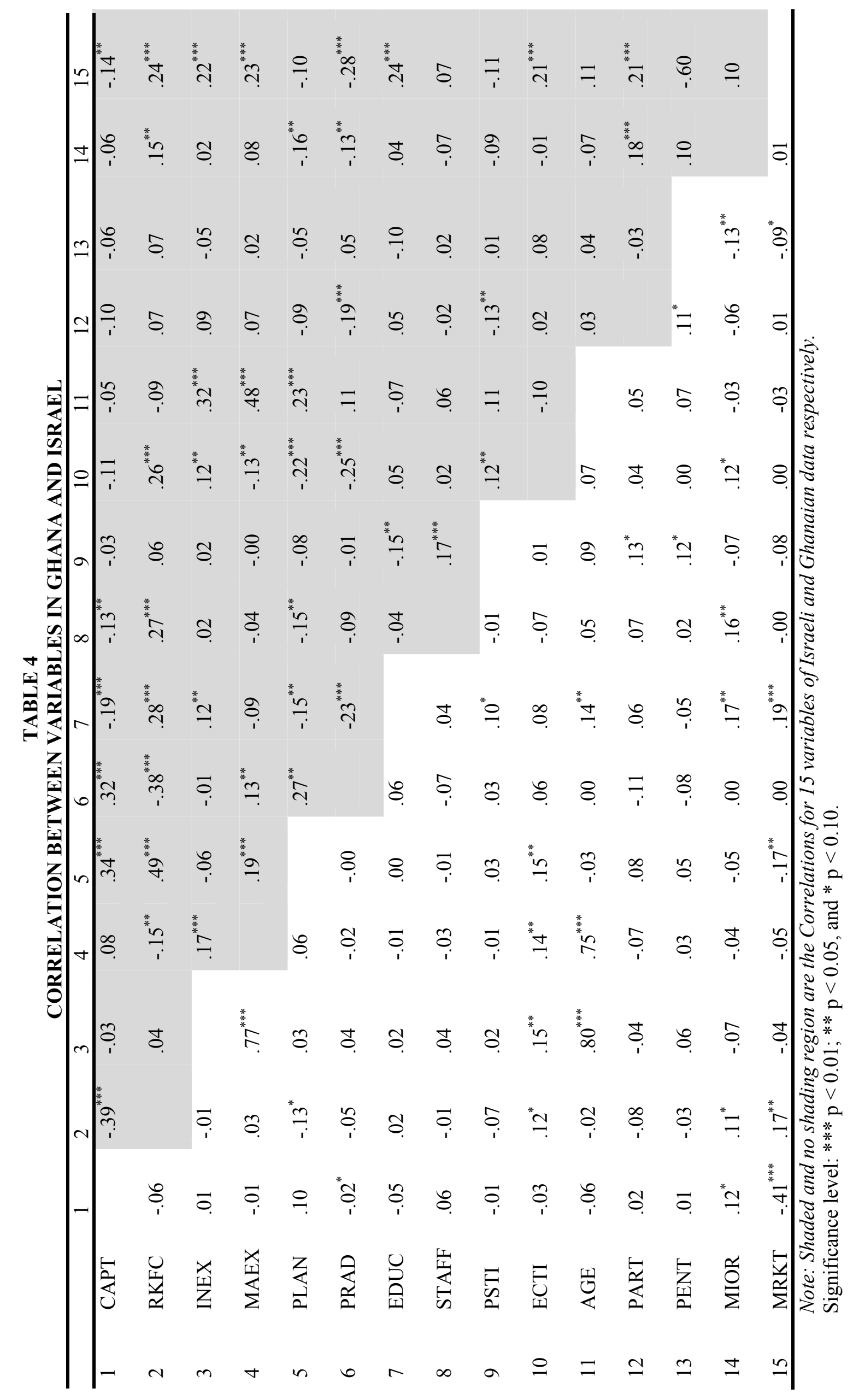




\section{TABLE 5}

LOGISTIC REGRESSION RESULTS

\begin{tabular}{|c|c|c|c|c|}
\hline \multirow[b]{2}{*}{ Independent Variables } & \multicolumn{2}{|c|}{ Israel (Middle East) } & \multicolumn{2}{|c|}{ Ghana (Africa ) } \\
\hline & Model $\beta$ & Model t-Sig. & Model $\beta$ & Model t-Sig. \\
\hline 1. CAPT & 0.57 & 0.004 & -0.94 & 0.000 \\
\hline 2. RKFC & -0.79 & 0.001 & 0.14 & 0.056 \\
\hline 3. INEX & -0.19 & 0.101 & 0.02 & 0.869 \\
\hline 4. MAEX & 0.07 & 0.579 & 0.01 & 0.945 \\
\hline 5. PLAN & 0.97 & 0.000 & 0.12 & 0.329 \\
\hline 6. PRAD & 0.50 & 0.013 & -0.07 & 0.432 \\
\hline 7. EDUC & 0.54 & 0.081 & -0.08 & 0.638 \\
\hline 8. STAFF & -0.15 & 0.492 & 0.03 & 0.797 \\
\hline 9. PSTI & -0.77 & 0.716 & 0.00 & 0.997 \\
\hline 10. ECTI & -0.56 & 0.090 & -0.21 & 0.014 \\
\hline 11. AGE & 0.14 & 0.021 & 0.02 & 0.709 \\
\hline 12. PART & 0.80 & 0.112 & 0.30 & 0.537 \\
\hline 13. PENT & 0.69 & 0.155 & -0.57 & 0.263 \\
\hline 14. MIOR & 0.16 & 0.774 & 0.10 & 0.161 \\
\hline 15. MRKT & 0.32 & 0.108 & 0.51 & 0.000 \\
\hline Constant & -8.06 & 0.017 & -0.10 & 0.636 \\
\hline \multicolumn{5}{|l|}{ Model Test Results } \\
\hline $\mathrm{N}$ & & 205 & & 208 \\
\hline -2 Log Likelihood & & 145.081 & & 131.47 \\
\hline Model Chi-square & & 139.065 & & 74.570 \\
\hline Model Significance & & 0.000 & & 0.000 \\
\hline R Square & & 0.657 & & 0.544 \\
\hline \multicolumn{5}{|l|}{ Classification Results } \\
\hline \multicolumn{5}{|l|}{ Correctly Classified (\%) } \\
\hline Success & & 84.6 & & 87.9 \\
\hline Failure & & 86.1 & & 85.2 \\
\hline Overall Classification (\%) & & 85.4 & & 86.5 \\
\hline
\end{tabular}

\section{Test of Difference and Multicollinearity}

The descriptive statistics test of differences between the successful and failed businesses in Table 3 reveals that Israeli successful businesses had eight significant variables. This indicates that if small businesses in Israel have (1) adequate capital, (2) maintain good record keeping and financial control, (4) have management experience, (5) have specific plans, (6) make use of professional advice, (8) select good staff, and have (10) good economic timing can increase their chances of success.

Similarly, Ghanaian had five significant differences. This indicates that if small businesses in Ghana start with (1) adequate capital, (2) maintain good record keeping and financial control, (5) have a specific plan, (12) start with partners and have (15) marketing skills prior starting the business can increase their chance of success. Interestingly, both continents test of differences results supports that adequate capital, record keeping and financial records, and the use of specific planning to start business reduces the likelihood of failure. 
In Ghana, the (11) mean age for successful entrepreneurs (34.51 years) is more than mean age for failed business owners (33.97 years); however, the small difference is not significant. Conversely, the age difference was significant in Israel. The mean age for success (31.50 years) is less than mean age for failed (34.21 years) businesses. However, the difference of 2.71 years is not meaningful, and is likely due to the large sample size making it easier to find differences. We cannot conclude that a couple of years of age to start a business will affect the probability of success.

Table 4, correlation analysis is run to examine the collinearity and degree of multicollinearity among the model variables. An r-value that is above 70 percent is considered highly collinear (Lussier, 2005). The results reveal that most of the correlations are relatively low except correlations for (3) industry experience and (11) age $(\mathrm{r}=.80)$; and (4) management experience and (11) age $(\mathrm{r}=.75)$. However, age of the entrepreneur, years of industrial and managerial experience are expected to be correlated because entrepreneurs cannot be young and have several years of experience. In addition, larger sample sizes are more likely to have significant correlations with low r-values. Hence, collinearity is not problematic for the study.

\section{Discussion of the Model Test Results}

For the predictive power of the model, a large $-2 \log$ likelihood and chi-square are the appropriate measures used to assess the overall significant of the model. The chi-square measures the combined effects of the 15 model variables whether they are different from zero. Also, -2 log likelihood measures the goodness of best fit of the model, and model significant level less than 0.05 supports that the model has predictive power. From Table 5, Israel and Ghana recorded a large $-2 \log$ likelihood of 145.081 and 131.478 respectively. Also, the result reports chi-square of 134.065 for Israel and 74.57 for Ghana. The model for both countries are statistically significant $(\mathrm{p}=.0 .000)$ indicating that the Lussier model has predictive power in Israel (Middle East) and Ghana (Africa), or the model fits the data and can accurately predict successful or failed of a group of businesses more accurately than random guessing over 99 percent of the time.

Ghana overall prediction of success or failure accuracy rate of 86.5 percent and Israel 85.4 percent are robust. In both countries, a specific business was correctly classified as successful or failed around 85 percent of the time, compared to 50 percent for random guessing. The accuracy rate for Israel and Ghana is higher than Lussier (1995) 70 percent; Lussier and Pfeifer (2001) 72 percent; Lussier and Halabi (2010) 63.2 percent; Lussier and Corman (1996) 75 percent; Guzman and Lussier (2015) 66.3 percent; Lussier et al. (2010) 78.4 percent; and Hyder and Lussier (2016) 80.9 percent. This supports that the Lussier model is very robust in Israel (Middle East) and Ghana (Africa) and can be used to predict success and failure of businesses.

Another comparison is the statistical significance of the individual variables. From Table 5, (1) capital is statistically significant $(\mathrm{t}$-value $<0.05)$ in Israel $(\mathrm{p}=0.004)$ and Ghana $(\mathrm{p}=0.000)$. This supports that businesses in Israel and Ghana need adequate capital to start and operate businesses to increase their chances of success. The result supports Hyder and Lussier (2016); as well as earlier similar study of Cooper et al. (1990, 1991), Reynolds and Miller (1989), and Reynolds (1987) that found capital as one of major predictor of business success. Also, (2) record keeping and financial control is significant in Israel $(\mathrm{p}=0.001)$ and close $(\mathrm{p}=0.056)$ in Ghana. Lussier et al. (2016) also found record keeping and financial control as significant variable that improves chances of success in Sri Lanka, South Asian economy. This supports, that keeping good records and financial controls contributes to success.

The need for $(5)$ planning is significant in Israel $(p=000)$ but not in Ghana $(p=0.329)$, and this implies that Africans may not need to develop specific plan to succeed in business as compared to Israel entrepreneurs. The difference may be due to smaller business ventures in the informal economy in Ghana with street walkers and street corner stands (Achua and Lussier, 2014) that dont need detailed plans.

Also, (6) professional advisors is significant in Israel but insignificant in Ghana. This could be that, successful businesses in developed economy like Israel uses professional advisors such as bankers, accountants, lawyers, economist, etc. in business activities. However, entrepreneurs in developing country like Ghana do not need professional advisors to succeed in business. Planning and professional advice 
have to do with the firm's human resources (Lussier and Pfeifer, 2001) and thus, human resources may have less of an effect on business success in Ghana than Israel.

In addition, (15) marketing skills is significant in Ghana $(\mathrm{p}=0.000)$ but not significant in Israel $(\mathrm{p}=$ 0.108). The result for Ghana supports Teng et al. (2011), Lussier et al. (2016), and Lussier (1996a) that found marketing skills as a significant determinant of business success. Thus, entrepreneurs in Ghana should start business with some level of marketing skills in order to increase their chances of success. In the informal economy with street walkers, street corner stands, and store owners, an important marketing factor is location (Achua and Lussier, 2014). In developed countries, location may not be important (Internet marketing) and is just one of the many marketing factors that lead to success. Another observation is that economic timing is significant in Ghana $(p=0.014)$ but not in Israel $(p=0.090)$.

\section{IMPLICATIONS AND CONCLUSION}

Predicting the success or failure of small businesses contributes significantly to entrepreneurship through the growth and sustainability of every economy (Lussier and Halabi, 2010). Thus, the present study contributes to both theory and practice. Currently, there is no unified theory or accepted success vs failure prediction model (Hyder and Lussier, 2016). Oviatt and McDougall (2005) and Bono and McNamar (2011) emphasized the need to test models in different countries to access their robustness. This study contributes to the literature by testing the Lussier success versus failure prediction model in Ghana (Africa) where there are no prior studies and compares results to the Middle East region, Israel. Empirical testing reinforces prior studies finding that Lussier model is robust for use as international model for predicting business success versus failure.

The logistic regression result concludes that Lussier model is valid for use in Ghana (Africa) and Israel (Middle East). Therefore, an entrepreneur that starts with adequate capital; keeps good record and financial control; has industry and management experience, develops specific plans; uses professional advisors; is educated; recruits and retains quality staff; has good product; start in good economic with partners, has parents who own businesses, have prior marketing skills, and is not a minority has a greater chance of being successful. Although the full model is a significant predictor of success vs failure, the importance of some of the model variables vary between Ghana and Israel. Five significant variables: adequate capital, good record keeping and financial control, use of specific plan, use of professional advisors and owners age contributes to business success in Israeli (Middle East) economy. In African region (Ghana), three variables: adequate capital, growing economy, and marketing skills have a greater effect on business success.

Based on the empirical results, the study supports the following practical implications.

- Educational institutions in Ghana and Israel can use the model to train students and entrepreneurs the significant factors that contributes to business success vs failure. Thus, Entrepreneurship courses or program curriculums can include the Lussier model.

- The model is useful to regulators, policy makers and consultant that can use the findings to train, educate, and advice aspiring entrepreneurs.

- The result support that adequate capital improves the chance of business success in Ghana and Israel regions. Hence, policy makers and financial institutions should consider programs that will offer low interest credit to entrepreneurs that can help them to start businesses with reasonable levels of capital. Also, government in both countries should provide adequate funds to entrepreneurs if who have specific business plan that is geared towards economic growth.

- Government agencies such as Small Business Authority of Israel (SBAI) and National Board of Small Scale Industries (NBSSI) in Ghana can benefit in direct and indirect ways through the reallocation of limited resources such as loans and aid towards higher potential businesses. This can strengthen these agencies to implement initiatives toward the development and investment of small businesses as a means of economic growth. 
- Potential lenders and investors can use the model along with their other predictors to assess the probability of a start-up ventures success vs failure.

- Lastly, consultants can train and educate their clients and assist them in applying the model to improves their probability of success.

As with all research, this study has some limitations. The first being the use a cross-sectional survey data collected at a single point in time. This can bring about some significant differences in the variables over time during growing or decline economy. Future study can use time series methods to affirm the portability of Lussier model across economic variations. Also, most of 15 independent variables were measured using 7-point subjective scales and this could result to self-perception bias responses from entrepreneurs. Further research can include more objective measures in predicting success or failure of business. Moreover, the study compares different countries results that have diverse cultural, legal and economic behavior. Future study can include some mediating or control variables on cultural differences, macro and micro environment indicators to assess the contributing factors of success versus failure prediction of small businesses.

The Lussier model is a subjective assessment of the probability of success vs failure. There is no simple score indicating either success or failure. Judgement is needed in assessing the variables. The model is a tool that can be used with the other methods that entrepreneurs, educators, consultants, investors, lenders, suppliers and other stakeholders can use to increase the probability of success - not in place of other existing methods.

Regardless of these limitations, the Lussier success versus failure prediction model is statistically significant in Israel $(p=0.000)$ and Ghana $(p=0.000)$. It will consistently predict a group of businesses as failed or successful 99 percent of the time. The model accurately predicted a small business as successful or failed 85.4 percent of the time in Israel and 86.4 percent in Ghana. In addition, the 15 variables explain a high 65.7 percent of the variance in the dependent variable distinguishing success versus failure in Israel, and 54.4 percent of the variance in Ghana. Therefore, the Lussier model is can help improve the rate of business success in Israel and Ghana. The study also supports the validity of the Lussier model being an international business success versus failure prediction model.

\section{REFERENCES}

Abor, J. Y. (2016). Entrepreneurial Finance for MSMEs: A Managerial Approach for Developing Markets, Springer.

Abor, J. and Quartey, P. (2010). Issues in SME development in Ghana and South Africa, International Research Journal of Finance and Economics, 39(6), 215-228.

Achua, C. F., and Lussier, R. N. (2014). Entrepreneurial Drive and the Informal Economy in Cameroon, Journal of Developmental Entrepreneurship, 19(4), 12 pages.

Altman, E.I. (1968). Financial ratios, discriminant analysis and the prediction of corporate bankruptcy, The Journal of Finance, 23(4), 589-609.

Altman, E.I. and Sabato, G. (2007). Modelling credit risk for SMEs: Evidence from the US market, Abacus, 43(3), 332-357.

Altman, E.I., Haldeman, R.G. and Narayanan, P. (1977) ZETATM analysis A new model to identify bankruptcy risk of corporations, Journal of Banking and Finance, 1(1), 29-54.

Appiah, K. O. (2011). Corporate Failure Prediction: Some Empirical Evidence from Listed Firms in Ghana, China-USA Business Review, 10(1), 32-41.

Argenti, J. (1976). Corporate Collapse: The Causes and Symptoms, McGraw Hill.

Barkham, R., Gudgin, G., Hart, M. and Hanvey, E. (1996). The determinants of small firm growth: an inter-regional study in the United Kingdom 1986-1990. Jessica Kingsley, London.

Barsley, G., and Kleiner, B. H. (1990). Small business management: Ensuring your clients success, National Public Accountant, 35(2), 30-33.

Beaver, W.H. (1966). Financial ratios as predictors of failure, Journal of accounting research, Vol. 4, 71 111. 
Blackwood, T. and Mowl, G. (2000). Expatriate-owned small businesses: measuring and accounting for success, International Small Business Journal, 18(3), 60-73.

Blum, M. (1974). Failing company discriminant analysis, Journal of Accounting Research, 12(1), 1-25.

Bono, J. and McNamar, G. (2011). From the Editors, Academy of Management Journal, 47(1), 657-660.

Bosma, N., Van Praag, M. and De Wit, G. (2000). Determinants of successful entrepreneurship, Research Report 0002, 1-42.

Bruins, A., op de Coul, J., Stigter, H. W. and van Uxem, F.W. (2000). What determines the success of a starter? Analysis of Success and Failure Factors of Entrepreneurs, Research Report, Research Institute for Small and Medium-sized Business in the Netherlands, Zoetermeer.

Bruno, A., Leidecker, J. and Harder, J. (1987). Why Firms Fail, Business Horizons, 36(2), 50-58.

Brush, C.G., Manolova, T.S. and Edelman, L.F. (2008). Separated by a common language? Entrepreneurship research across the Atlantic, Entrepreneurship Theory and Practice, 32(2), 249266.

Buyinza, F., Mutenyo, J., Kakande, N., and Banga, M. (2017). Determinants of firms startup size and performance of small and medium scale enterprises (SMEs): Empirical Evidence from Uganda. Journal of Applied Business and Economies, 19(12), 46-56.

Carrero-Morales, G. I. (2015). Factors affecting the success and failure of small and medium enterprises in Puerto Rico, 60th Annual ICSB World Conference, Dubai: ICSB, 111-119

Cooper, A., Dunkelberg W., Woo C. and Dennis W. (1990). New Business in America: The Firms and Their Owners. Washington, DC: The NFIB Foundation.

Cooper, A., Gascon, J. and Woo C. (1991). A Resource-Based Prediction of New Venture Survival and Growth, Academy of Management Proceedings, 113-119.

Crawford, G. L. (1974) An Analysis of Management Factors that May Contribute to the Success or Failure of Selected Small Retailers. University of Arkansas.

Cressy, R. (1996). Are business startups debt-rationed? The Economic Journal, 1253-1270.

Deakin, E. B. (1977). Business failure prediction: an empirical analysis, Chapter, 4, 72-88.

Dennis Jr, W. J. and Fernald Jr, L. W. (2001). The Chances of Financial Success (and Loss) from Small Business Ownership, Entrepreneurship: Theory and Practice, 26(1), 75-83.

Dess, G.G., Lumpkin, G.T. and Covin, J.G. (1997). Entrepreneurial strategy making and firm performance: Tests of contingency and configurational models, Strategic Management Journal, 18(9), 677-695.

Duchesneau, D.A. and Gartner, W.B. (1990). A profile of new venture success and failure in an emerging industry, Journal of Business Venturing, 5(5), 297-312.

Dun and Bradstreet (1995). Business Failure Record. New York: Dun and Bradstreet.

European Union (2012). EU SMEs at the crossroads, Annual report on small and medium-sized enterprises in the EU, 2011/12.

Flahvin, A. (1985). Why small businesses fail, Australian Accountant, 55(9), 56-72.

Gaskill, L. R., Van Auken, H. E. and Manning, R. A. (1993). A factor analytic study of the perceived causes of small business failure, Journal of Small Business Management, 31(4), 18.

Guzman, J.B. and Lussier, R.N. (2015). Success Factors for Small Businesses in Guanajuato, Mexico, International Journal of Business and Social Science, 6(11), 1-7.

Gyimah, P. and Boachie, W.K. (2018). Portability of multiple discriminant analysis prediction model of listed firms: an emerging market perspective, Research Journal of Accounting and Finance, 9(6), 94-99.

Halabi, C. E. and Lussier, R. N. (2014). A model for predicting small firm performance: Increasing the probability of entrepreneurial success in Chile, Journal of Small Business and Enterprise Development, 21(1), 4-25.

Hoad, W. M. and Rosko, P. (1964). Management factors contributing to the success or failure of new small manufacturers (Vol. 41). Bureau of Business Research, Graduate School of Business Administration, University of Michigan.

50 Journal of Applied Business and Economics Vol. 21(3) 2019 
Huck, J.F. and McEwen, T. (1991). Competencies needed for small business success: perceptions, Journal of Small Business Management, 29(4), 90.

Hyder, S. and Lussier, R.N. (2016). Why businesses succeed or fail: a study on small businesses in Pakistan, Journal of Entrepreneurship in Emerging Economies, 8(1), 82-100.

Israel Ministry of Industry, Trade and Labor - MITL (2010). ISRAEL: Global Center for Breakthrough Innovation. Ministry of Industry, Trade and Labor, Investment Promotion Center. http://www.moital.gov.il/NR/rdonlyres/D20FF2AA-23AA-4D5F -8D448CD1DD61127B/0/Innovationbrochure2010.pdf. (retrieved April 26, 2018).

Kangasharju, A. (2000). Growth of the smallest: Determinants of small firm growth during strong macroeconomic fluctuations, International Small Business Journal, 9(1), 28-43.

Kennedy, C. R. (1985). Thinking of opening your own business? Be prepared! Business Horizons, 28(5), $38-42$.

Lauzen, L. (1985). Small business failures are controllable, Corporate Accounting, 3(3), 34-38.

Lussier, R. N. (1995). A nonfinancial business success versus failure prediction model, Journal of Small Business Management, 33(1), 8-20.

Lussier, R. N. (1996a). A startup business success versus failure prediction model for the retail industry, The Mid-Atlantic Journal of Business, 32(2), 79-92.

Lussier, R. N. (2005). A success versus failure prediction model for the real estate industry, American Journal of Business, 20(1), 47-53.

Lussier, R.N., Bandara, C. and Marom, S. (2016). Entrepreneurship success factors: an empirical investigation in Sri Lanka, World Journal of Entrepreneurship, Management and Sustainable Development, 12(2), 102-112.

Lussier, R. N. and Corman, J. (1996). A business success versus failure prediction model for entrepreneurs with 0-10 employees, Journal of Small Business Strategy, 7(1), 21-36.

Lussier, R. N. and Halabi, C. E. (2010). A three-country comparison of the business success versus failure prediction model, Journal of Small Business Management, 48(3), 360-377.

Lussier, R.N. and Pfeifer, S. (2000). A comparison of business success versus failure variables between U.S. and Central Eastern Europe Croatian Entrepreneurs, Entrepreneurship Theory and Practice, 24(4), 59-67.

Lussier, R.N. and Pfeifer, S. (2001). A cross national prediction model for business success Journal of Small Business Management, 39(3), 228-239.

Marom, S. and Lussier, R.N. (2014). A business success versus failure prediction model for small businesses in Israel. Business and Economic Research, 4(2), 63.

McQueen, J. (1989). The causes and lessons of business failure, Credit Management, 10, 24-25.

Morris, R.C. (1997). Early Warning Indicators of Corporate Failure: A critical review of previous research and further empirical evidence: Ashgate.

Neshamba, F. (2000). Growth and transformation among small business in Kenya. United Kingdom: The Nottingham Trent University.

OECD-Organisation for Economic Co-operation and Development (2015) SME and entrepreneurship: OECD, Paris, available at http://www.oecd.org/cfe/smes (retrieved April 28, 2018).

Ohlson, J.A. (1980). Financial ratios and the probabilistic prediction of bankruptcy, Journal of Accounting Research, 18(1), 109-131.

Oviatt, B.M. and McDougall, P.P. (2005). Defining international entrepreneurship and modeling the speed of internationalization, Entrepreneurship Theory and Practice, 29(5), 537-554.

Pena, I. (2004). Business incubation centers and new firm growth in the Basque country, Small Business Economics, 22(3), 223-236.

Rauch, A. and Frese, M. (2000). Psychological approaches to entrepreneurial success: A general model and an overview of findings International Review of Industrial and Organizational Psychology, 15(1), 101-142. 
Rauch, A., Frese, M. and Utsch, A. (2005). Effects of human capital and long-term human resources development and utilization on employment growth of small-scale businesses: a causal analysis, Entrepreneurship Theory and Practice, 29(6), 681-698.

Reynolds, P. D. (1987). New firms: societal contribution versus survival potential, Journal of Business Venturing, 2(3), 231-246.

Reynolds, P. and Miller, B. (1989). New firm survival: analysis of a panels fourth year. Frontiers of Entrepreneurship Research, Babson College, Wellesley, MA, 159-172.

Rosner, R. L. (2003). Earnings manipulation in failing firms Contemporary Accounting Research, 20(2), 361-408.

Sage, G. (1993). Entrepreneurship as an economic development strategy, Economic Development Review, $11(2), 66$.

Santarelli, E. (1998). Start-up size and post-entry performance: the case of tourism services in Italy, Applied Economics, 30(2), 157-163.

Schutjens, V. A. and Wever, E. (2000). Determinants of new firm success, Papers in Regional Science, 79(2), 135-159.

Sommers, W. P. and Koc, A. (1987). Why most new ventures fail (and how others dont), Management Review, 76(9), 35.

Storey, D.J. (1994). New firm growth and bank financing, Small Business Economics, 6(2), 139-150.

Teng, H. S. S., Bhatia, G. S. and Anwar, S. (2011). A success versus failure prediction model for small businesses in Singapore, American Journal of Business, 26(1), 50-64.

Thompson, R. (1988). Business plans: Myth and reality, Nations Business, 76(8), 16-23.

Vesper, K. (1990). New Venture Strategies, Englewood Cliffs, NJ: Prentice Hall.

Wight, C. (1985). Business failures: Early diagnosis and remedies, Australian Accountant, 30-39

Wiklund, J. and Shepherd, D. (2003). Aspiring for, and achieving growth: The moderating role of resources and opportunities, Journal of Management Studies, 40(8), 1919-1941.

Wood, D. L. (1989). Why new businesses fail and how to avoid disaster, Corporate Cash Flow, 10(8), 26-27.

Yusuf, A. (1995). Critical success factors for small business: Perceptions of South Pacific entrepreneurs, Journal of Small Business Management, 33(2), 68. 